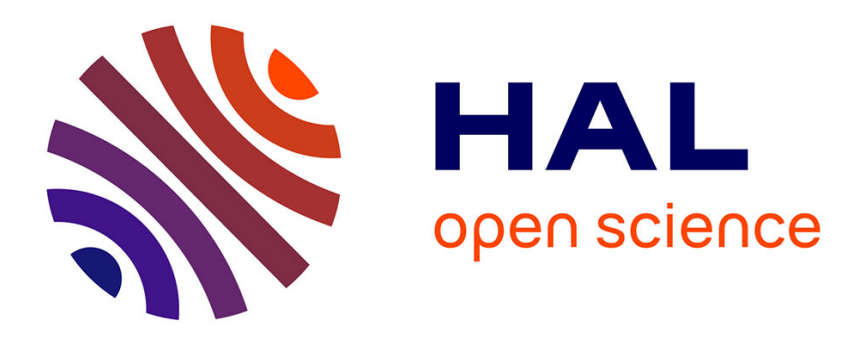

\title{
Development of manager-academics at institutions of Higher Education in Catalonia
}

\author{
Diego Castro, Marina Tomas
}

\section{To cite this version:}

Diego Castro, Marina Tomas. Development of manager-academics at institutions of Higher Education in Catalonia. Higher Education Quarterly, 2011, 65 (3), pp.290. 10.1111/j.1468-2273.2011.00490.x . hal-00657594

\section{HAL Id: hal-00657594 \\ https://hal.science/hal-00657594}

Submitted on 7 Jan 2012

HAL is a multi-disciplinary open access archive for the deposit and dissemination of scientific research documents, whether they are published or not. The documents may come from teaching and research institutions in France or abroad, or from public or private research centers.
L'archive ouverte pluridisciplinaire HAL, est destinée au dépôt et à la diffusion de documents scientifiques de niveau recherche, publiés ou non, émanant des établissements d'enseignement et de recherche français ou étrangers, des laboratoires publics ou privés. 


\section{Higher Education Quarterly}

\section{Development of manager-academics at institutions of Higher Education in Catalonia}

\begin{tabular}{|r|l|}
\hline Journal: & Higher Education Quarterly \\
\hline Manuscript ID: & HEQU-May-10-0036.R1 \\
\hline Manuscript Type: & Article \\
\hline Keywords: & $\begin{array}{l}\text { academic-managers, Higher Education, management, development } \\
\text { managers }\end{array}$ \\
\hline \multicolumn{3}{c}{ SCHOLARONE } \\
ManuSCripts \\
$\quad$
\end{tabular}




\begin{abstract}
Managers at Spanish universities are having to deal with increasingly complex managerial tasks as a result of current changes in higher education. This paper presents the results of a study into the professional development of deans and department heads at universities in Catalonia. At management level, these universities are typically based on an elected, rotating model rather than an appointed or permanent one. The findings from 23 qualitative interviews and a focus group identified three phases in the development of academic management: learning and contextualisation, development of functions and the institutional projection and transmission of management tasks.
\end{abstract}

\title{
Keywords
}

Academic-managers, higher education, management, development managers

Trends in higher education management 
This article examines developments in the management roles performed by academicmanagers in higher education institutions in Catalonia. As defined by Deem and Brehony (2005), manager-academics are teachers or researchers who take on management roles in higher education, whether temporarily or permanently. The manager-academics involved in this study were faculty deans and department heads with managerial responsibilities of a non-professional and temporary nature at institutions where managers are elected on the basis of representativeness criteria.

As society and universities undergo rapid change, most European countries are having to respond to a widespread need to rethink management and managerial tasks at university level (EURYDICE, 2008). Different models of leadership at public universities have been studied and debated with increasing intensity in recent years. European governments have shown a growing lack of confidence in traditional models of management at institutions of higher education (Deem et al., 2007). As a result, universities have been forced to restructure their management model and the manner in which they monitor performance. Concern about training provision for academicmanagers in the United Kingdom is reflected in studies such as that by Whitchurch (2007), which analyses changes in the roles of managers. In the Leadership Foundation Getting to Grips publications, Watson and Huxley (2009) also put forward areas of governance that may be of interest to leaders and managers elsewhere in higher education.

Bricall (2000) coordinated a national report on the situation of the Spanish university system. This included a diagnostic dimension and a set of alternative measures to improve university management and governance. This diagnosis concluded that the 
Spanish university system is based on a managerial model of an elective, nonprofessional and transitory nature. The first proposal was to increase institutional autonomy and external social control. The second proposal geared to improvement was to professionalise the role of university managers. The third proposal suggested that greater value should be accorded to management roles assumed by academics as part of their long-term career development. Finally, some stimulus to innovation was proposed in university management to increase competitiveness among higher education institutions.

The growing trend towards university autonomy has meant that in a significant number of Europe's higher education academics have assumed many of the management responsibilities previously held by educational administration (Larsen, Maassen \& Stensaker, 2009). Nowadays, universities demonstrate their ability to respond adequately to society's needs by using resources responsibly and maintaining standards of excellence in their principal roles of teaching and research. The increasing trend, characterised by encouraging autonomy and accountability, has changed the traditional system of governance addressed to promote self-management among academics (Sporn, 2003). New models of government are focused on the redistribution of both responsibilities and the power of decision-making among the different internal and external stakeholders, with an eye to broader accountability. A key coordination approach to university management is to promote and enhance links between government/state and public universities. This involves a redefining of autonomy and new strategies for social responsibility at university level. University governance refers to the balance between the academic corporation model and the management model, based on a professional process of decision-making. The university functional structure provides a further control mechanism. Nowadays it is necessary to define the degree of 
rigidity or flexibility university structures have in dealing with the changing environment. This requires institutions to analyse the usefulness of their central organisation as well as at other structural levels, such as university departments.

Conventionally, university management can be subdivided into three models that overlap to a certain degree: the bureaucratic model, the collegiate model and the market model. Clark (1983) defined these models of university management by analysing three axes: the state, the academic corporation and the market. Overall, the model of university management applied in Catalonia might be defined as the collegiate model with some features of the bureaucratic model.

Although the academic model displays certain advantages, many authors have also identified a number of weaknesses (Mora, 2000; Bricall 2000). First, one of the most frequent criticisms concerns the low interest shown by academics in taking responsibility for university management. This may be explained by the fact that academics are usually more orientated towards teaching and research activities. However, the weaknesses displayed by other management models have been useful in helping to redefine the traditional model. Second, the matrix structure model of academic management has also been identified as a problematic factor. This structure makes a distinction between two clear profiles: academic and administrative management (Larsen, Maassen \& Stensaker, 2009). Third, weaknesses have also been exposed by academics, whose main concern is the lack of training to cope with management functions at universities (Smith, 2008). Indeed, even rectors have been found to demonstrate a low level of ability in dealing with university financial management. However, recognition of a lack of training among university personnel is not always at the root of staleness in university government (Tomàs, 2006). Criticism has also been levelled at the implementation of different models of university 
management that are more professionalised and based on the market model. Research by Deem et al. (2007) into department heads, deans and senior managers concluded that the concept and use of managerialism has both infiltrated the daily life of manageracademics and changed typical power relations. New managerialism is not only a means to reform governance, it also represents a change in the conceptualisation of the university. When the traditional model is contrasted with more professionalised models, its main weakness concerns the way in which the university is financed. The chronic lack of resources at many public universities hampers their ability to deal with current social demands. Given the weaknesses surrounding the different management models, Trakman (2008) suggests the development of a mixed model that incorporates the advantages of each. The mixed model is useful because it addresses the specific needs of each university and focuses on: the research and creation of structural knowledge; improving revenue-generating activities; increasing funding from governmental sources; innovation geared to securing economic development; academics having the freedom to produce research in their own areas of expertise; building critical mass in those disciplines or areas in which the university displays excellence; and providing a context in which students are given the opportunity to develop and achieve their maximum potential.

In short, management of higher education institutions in Catalonia, as in other European countries, is a matter that gives cause for concern. In many countries certain aspects of the national higher education policy are currently under governmental review. These include institutional autonomy, the professionalisation of managers and competitiveness among different universities. 


\section{Phases of development in managerial positions}

The concept of an academic career has not properly been defined in Catalonia, despite the proposal included in the Bricall Report (2000). This report argued that professional careers must be oriented towards a natural expectation of professional promotion. In practice, however, a professional career is necessarily linked to human resources management at university level and in most cases reflects human resource turnover in the educational system.

A comparison of the evolution of professional careers and management positions at universities reveals similar levels of development (Tumbull \& Edwards, 2005). The institutional performance of management positions show a certain pattern of evolution characterised by an artificial logic, in which it is easy to find a common thread running throughout the entire evolutionary process. From a phenomenological analysis, this implies the overlapping of different phases. According to Akerlind (2008), for example, individual features are also related to workplace development at universities. In addition, however, organisational and social characteristics influence the role of individuals at their place of work. Management positions can be categorised according to a number of taxonomic orders. Most of these note that, first, the evolutionary process through phases of development is nonlinear and any of its phases may be altered or repeated depending on how it is influenced by individuals, groups or the organisational culture. Second, there is no homogeneous development and each person can develop his or her own specific process. Professional reality therefore incorporates a high degree of pluralism and complexity. Third, the characterisation of phases allows the projection of different perspectives, conflict identification and resolution and subsequent intervention. Fourth, it is a cyclical model, during which the incorporation of a new 
responsibility or place of work reproduces, to a greater or lesser extent, all the development phases.

Robbins (1987) identified five phases relating to a person's performance in the place of work: integration, socialisation, maintenance, negotiation and memory.

Integration occurs when subjects comes into contact for the first time with their new professional context. Integration into the new institutional dynamic is crucial and also includes relationship with the environment: contacts, people, groups, influences, etc.

Socialisation includes not only implicit but also explicit acceptance of the new place of work and its characteristics. During this period several processes occur, including assimilation of, and adaptation to, the dominant cultural patterns and development of the subject's own strategies for acting in the context.

During the maintenance phase subjects consolidate their ability to integrate and opportunities for participation and involvement are enhanced. In addition, professional development takes place during this phase. Innovation and change are common during the maintenance phase because there is more opportunity to promote technical and relational aspects. Control and security are also characteristic features.

With learning and innovation complete, subjects pass through a negotiation phase, during which they incorporate negotiation strategies with a view to extending their functions or competences. If negotiation is successful, it may result in a redefining of the workplace and a new approach. This is a preliminary phase, however.

Performance at the new workplace is influenced by past experiences: memories. Relationships and experiences among people often yield synergies that, at some point in the future, may be consolidated and institutionalised. Importance is attached to 
reminiscences, memories and associations, since these affect both the personal and institutional background.

In summary, analysis of the development phases of a manager's positions concludes that phases are neither homogeneous nor linear in time. Conventionally, literature identifies five phases (integration, socialisation, maintenance, negotiation, memory that will be contrasted in the research.

\section{Management in Catalan Higher Education}

Having elaborated the theoretical background to university management and the phases of development of managerial positions, this section describes the situation specific to universities in Catalonia.

Catalonia is one of 20 autonomous regions of Spain established by the democratic constitution of 1978. Since the 1980s the state has undergone a process of increasing decentralisation, devolving power to the various autonomous communities in ways which, despite similarities, also show up significant differences. With a population of seven million, Catalonia is a region with a long history, a language of its own and distinct traditions, many of which date back to the medieval period. Today it enjoys very wide powers in many areas of administration, including its universities. In practice, this means that although certain general aspects come under state control, the specific regulations and administrative management of Catalan universities are the responsibility of the regional government, in this case the Generalitat de Catalunya (Catalan Autonomous Government). 
Powers over university management were transferred to the autonomous communities by Spanish central government in 1983. Central administration retained only a few responsibilities, such as curricular criteria and the issuing of degree certificates. In 2003, Catalonia promulgated the Law of Universities of Catalonia (Llei d'Univeristats de Catalunya), which adapted state regulations to the specificities of the autonomous community. The university system in Catalonia is made up of twelve university centres (eight public and four private) and has its own agency for external assessment. The governance and management of public universities have features that differ to those of private universities, particularly concerning appointments to unipersonal positions. Specifically, in private universities these positions are appointed and not elected as in public universities.

University governing bodies can be classified on the basis of two variables: composition and scope of influence. The composition of governing bodies can be unipersonal or collegiate; their scope of influence may be general or peripheral (also called territorial). This can be represented in tabular form (figure 1).

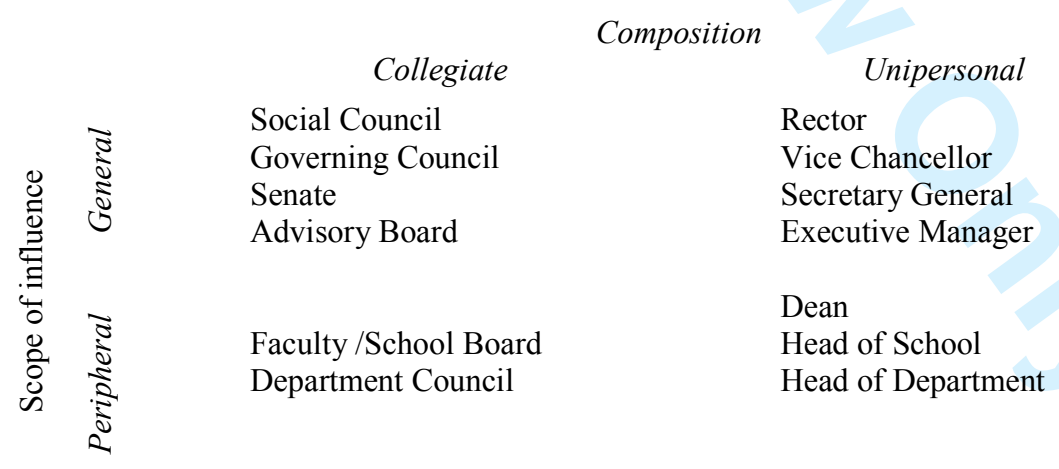

Figure. 1. Classification of university governing bodies 
In particular, department heads and deans take on fundamentally different roles and functions. Whereas department heads take care of human resources management and research, deans are responsible for organisation of the curriculum, teaching and timetabling.

What characterises the unipersonal roles in particular is that they are elected and based on principles of representativeness, the style of management is non-professional and there is a transient nature to the positions. This type of election is based on representative features and a matrix structure. The internal system of organisation, based on the Napoleonic theory of university management, is dominated in the main by the academic corporation model, in which teaching staff often have considerable organisational power, orchestrated through an institution-wide association. According to Mintzberg (2003) this management style is linked to 'professional bureaucracy', as well as to a well-structured system of different institutional constituencies. This not only allows teaching staff to form an association but also permits similar associations of students as well as administrative and service personnel. Given that teaching staff are organised according to academic ranking, the whole educational system is divided into different levels. Consequently, academic organisation is structured along the lines of an elementary professional bureaucracy. A study of universities in Catalonia identifies a permanent matrix structure (Mintzberg, 2003), which combines a dual authority pattern giving them their own functions and decision-making powers at both administrative and academic levels.

The administrative level includes personnel who support and service academic activities, as well as the institutional activities of management. The academic level includes the teaching and research personnel in charge of scholarship, research and 
teaching. The management level of Spanish universities is characterised by an elected, rotating model.

First, manager-academics are elected by the teaching staff; in most cases those elected are people in senior positions. According to the levels of authority defined by Clark (1995), the university in Spain has split power into two branches: the high-ranked academics (academia) and managers (bureaucracy).

Second, university management is also characterised by non-professionalism. The representativeness of teachers is traditionally present in a university culture, even in the process of decision-making at collegiate and unipersonal level. Teachers usually assume tasks in administrative positions at faculties and departments and most of them accept such responsibilities voluntarily and temporarily. This has resulted in a nonprofessionalised management model (Mora, 2000). Traditionally, assessment of teachers' ability has placed a greater focus on evaluating teaching and research skills than on aptitude for institutional management.

A new university staff law is currently pending approval by the Ministry of Education (Ministerio de Educación, 2010). This new law proposes that responsibilities of university administration should not limit the development of teachers in their teaching and research activities. The managerial model of faculties and departments is therefore not oriented towards a professional model.

Third, academic management is also characterised by temporality. Once elected, teachers are required to exercise their mandate for a certain period of time. The current regulation specifies that department heads and deans can only exercise this position for three years; extension of this mandate for three more years is only possible upon reelection. Representation and leadership are always limited by time and dependent on the 
decision of colleagues and those who elected them (Mora, 2000; Castro, 2006). This approach to internal government is in line with the Latin concept of primus inter pares (first among equals).

In summary, institutional management is subordinated to terms of mandate carried out by different teachers. Managers are renewed every three or six years, along with a number of changes in policies and performance.

\section{Methodology}

The methodology used for the study was mainly qualitative (Tesch, 1990). Of the various types of qualitative study in use, the approach selected was the systemic perspective of grounded theory (Strauss and Corbin, 1998). The aim of this approach was to generate theoretical constructs which, along with substantive codes and categories and their properties, develop a theory that encompasses and explains as much behavioural variation as possible (Munhall, 2001).

The research issues that guided this approach focused on perceptions of professional development of academic-managers and analysis of the conditions in which they exercise their mandate as unipersonal entities.

Two techniques were used for data collection: interviews and focus groups. Semistructured, in-depth interviews were drafted with a focus on the principal topics of the research. The data obtained from these interviews were then presented to a focus group. The study then looked at unipersonal entities classified within the public university system, specifically the deans and department heads. Twenty-three interviewees, drawn from four public universities (all in the Barcelona metropolitan area), were interviewed. 
Three types of interview were prepared according to the type of interviewee: 1) Twelve interviews with academics in managerial positions or with management functions in school departments or faculties; 2) Eight interviews with experts on educational assessment from government and management agencies; 3) Three interviews with personnel in administrative and support functions. The interview guide posed questions about each interviewee's perception of the workplace, its importance, tasks and repercussions; the style of management at the university and its conditions; career opportunities and development; common problems and barriers; and leadership styles.

The final sample was selected according to non-probabilistic criteria, the interviewees' representativeness and the model of theoretical sampling (Flick, 2004). Data from the interviews were then analysed and systematised using Aquad software (version 6). A preliminary report was drafted, establishing the most relevant themes extracted from the interviews, as well as any issues or themes considered controversial. This report then formed the basis for the second phase of data collection, in which a group of nine academics took part in a focus group. These participants were selected for the focus group on the grounds of their expertise in management in the context of higher education in Europe.

\section{Findings}

The key finding identified that manager-academics not only evolve throughout their period in management, they also go through a number of phases defined by common factors. These phases can be grouped into three: early, development and final.

\section{Early phase}

The main feature of this phase is the teacher's contextualisation and adaptation to his or her new managerial role. This phase implies the need to know the institutional context, 
understand and analyse the dynamics of different groups and individuals and become familiar with routines and bureaucracy as well as other aspects key to this kind of position. The duration of this phase might coincide with the first cycle of administrative work, leading managers to have to deal simultaneously with the administrative cycle and their other tasks and responsibilities, including academic work.

It is clear that managers do not appreciate the complexity of their responsibilities until they have completed the whole of the first year, particularly if they have had no previous experience in managerial positions. There is a need to contextualise themselves with their new tasks. The administrative cycles to a large extent determine management by the deans and department heads. (Gines, expert)

Detailed analysis identified three key characteristics: strong motivation; discretion in the decision-making process; and an exercise of power that might be categorised as 'low-intensity' in nature. Respondents agreed that this was the most interesting phase, given the degree of motivation and high expectations it engendered. There is also a strong eagerness among people to achieve their maximum potential, although the need to act with caution and prudence is also present during such a process. In a context in which lack of experience and ignorance of certain issues is prevalent, the recommended approach is to tackle urgent matters first. New managers tend to continue with past directives, refusing initially to propose radical measures.

During the initial phase you already have your own ideas about what you want to do. Your aim is to develop your previous manifesto. Then you get the feeling of being wrong, so in order to avoid any mistake you review what has been done previously. During my first months I was very anxious to get on with the job, yet at the same time I was very circumspect. Before proposing any plan and proceeding, I took care to see if there was an approach I could use that was similar to the way the previous manager did things. (Jon, department head) 
The main difficulties reported by academic-managers centred on the chairing of meetings, particularly those involving large numbers, the possibility or expectation of conflict and, in addition, the risk of being wrong-footed as a consequence of insufficient knowledge of the law or internal organisational regulations. Most of these concerns lead academic-managers to undertake new negotiation and consensus processes prior to formal meetings, particularly with certain interest groups, so as to avoid conflict situations but thereby suffering a loss of recognition as a manager on occasions. Knowing the micro policy of different groups is crucial during this phase.

There are also certain dynamics and procedures that are strongly ingrained into staff behaviour and some everyday facts that can surprise you. If you want to avoid making mistakes, you must observe others, maintain an open attitude and promote dialogue with all members of the organisation. It is also important for academic-managers to assume the strategy of developing closer relationships with lead teachers, consulting them and taking their advice. You have to be familiar with internal policy and informal systems. (Steve, expert)

Some factors identified as important included a need for familiarity with the different organisational units (groups, people, commissions), the diagnosis of teamwork to improve cohesiveness, the diffusion of managerial strategies and meetings with colleagues. This phase is considered a rapid learning process and managers are constantly required to refresh their knowledge of important issues and concerns:

You certainly have to look all around you to realise what is happening. Never admit as true a decision you have not taken. The first thing I did was to schedule meetings with departments, listening to them and making approaches before they came to me. There was a certain amount of alienation at times. There were always meetings involving new issues. Since I had never been told about 
any of these prior to my appointment, I was forced to get up to speed with them pretty quickly. (Paul, dean)

\section{The development phase}

The development phase is mainly concerned with implementing the principle functions of manager-academics, which in Catalonia form part of higher education law or are assigned by university statutes and relevant outside agencies. This phase is defined as highly active.

I spend most of my time in personnel management, with tasks ranging from the contracting process to the resolution of interpersonal problems. This situation is now having profound effects on the teaching staff and one is required to spend a great deal of time listening to them. I also think it is important to improve research into quality and to analyse the impact of bureaucracy and administrative matters at department level. (Alicia, department head)

A manager's responsibilities during this phase are divided into two groups. The first concerns institutional functions: meetings, representative commissions, interventions on conflict resolution, communication, bureaucratic processes and the process of negotiation (mainly demands for new resources). The second group covers personnel management at the academic and administrative or service level. Several factors relating to current policy applying to Catalonian universities were found to affect the data obtained. Most of the interviewees mentioned the process of convergence between Catalonian and Spanish universities and the European Higher Education Area. Some aspects were highlighted in particular, such as the new university curriculum, new systems of coordination and the design of degree and post-degree programmes.

Sometimes there is not enough time, the amount of work is overwhelming. In the teaching process, for instance, the environment is ambivalent and you must 
Management during this phase is orientated towards three key aspects: new projects; the opportunity for managers to take greater control over their work; and the rise in factors that demand greater confidence, such as chairing meetings. Those academic-managers in charge of the application of disciplinary procedures or other institutional regulations reported higher levels of decision-making and also felt more comfortable applying these than in the first stage. An increased capacity for initiative-taking was noted, as well as a higher level of confidence regarding personal and teamwork skills. Experience and learning facilitated the proposal of innovative activities.

\section{Final phase}

The final phase is characterised by the completion of previously initiated projects, institutionalisation of these into the organisational culture and preparation for leaving the managerial role and returning to academic life. It could be called the 'way out' phase and is sometimes shorter than the other two phases identified. During this final period the manager effectively controls different administrative functions, has a broad understanding of all the major issues and feels less pressure from colleagues on factual and strategic matters. During this phase academic-managers show greater initiative and their leadership ability reaches its highest level. 
From my point of view, the moment when managers know most coincides with the termination of their mandate. With the experience they have gained over these years they are more independent, more creative and more assertive. It is a pity to waste all this learning and apprenticeship. (Lisa, expert)

The end of the management period also means managing the transition at the point of changeover, identifying what managers want the institution to retain as a result of their leadership, consolidating this within the institution during the transfer of mandate and discussing key issues to be considered and handed on in the transition process to a new person or team. Those interviewed reported that design and anticipation of this institutionalisation are highly relevant during this phase and the leader must take full responsibility for it. The tasks involved in preparing for handover to a new manager are of utmost importance, since they are factors that ensure the transfer of power is successful. These tasks include motivating teachers to submit new project applications or curriculum developments and ensuring that the process established under the institutional regulations for transfer of power and the managerial role is fully accomplished, both before and after transition to a new leader.

My work did not end the day I left my position, since I had to ensure that the colleague succeeding me was able to develop his or her own project. Even if you do everything right, you still have to plan an exit strategy: failure to do so may cause problems. You have a lot of institutional responsibilities, you belong to the department. (Andrew, department head)

At the end of their term in office, manager-academics face a number of new challenges. The first is of a more formal nature and involves a smooth transfer of responsibility to the successor. The second is more functional and involves the efficient handover of all outstanding issues to the new manager. Finally, measures must be put in place that take 
account of a manager's personal characteristics to ensure the outgoing manager once again becomes a full member of the department or faculty. During this phase the former manager is required to focus exclusively on academic activities, teaching and research.

The interviews revealed that there is no tradition of taking on various consecutive mandates. Those performing unipersonal functions considered that such positions demand a high level of personal and professional commitment. Consecutive election to further management positions may have a negative impact on a person's academic career. The minority of applications made by deans or department heads for consecutive management periods are mainly motivated by unfinished projects, explicit support from colleagues or a lack of other applicants capable of ensuring a clean transition:

Three years is more than long enough to achieve what you set out to achieve. If you cannot do it in three years, you are even less likely to do it in six. A six year-period is too long and would probably have a negative effect on your curriculum vitae. I cannot imagine myself applying for the position of dean a second time, absolutely not. (Maria, dean)

A retiring manager's background and experience in former positions is key to the process of appointing a successor. Few universities elect people with little or no experience or without any previous background. Such a tradition is widely supported by the academic community because it ensures continuity in the management model and the establishment of institutional principles. In addition, this tradition implies a certain training model for management issues that is highly valued in a non-professionalised context.

I think many deans and department heads have already exercised low-level responsibilities prior to taking on management roles. To present oneself without 
any training or experience is tantamount to committing professional suicide. (Gines, expert)

The findings and recommendations of external agencies for the assessment of academics (for example in relation to acquisition of tenure or other forms of promotion) are very positive about the fact that most university statutes allow a period of up to one year of study leave for those who have served a term as dean or head of department. The sabbatical period must be used for personal update of a scientific, artistic or technological nature:

Assessment tasks of teachers must also include their management functions, all these activities are very important during our careers. You cannot do everything well and everything at the same time. The current system is a trap, since performing a management function is not well regarded in a system where the most prized goal is research. If the system remains as it is, nobody will want to go into management. If your focus is solely on management activities, then you must be judged on these exclusively; it is senseless to make not being a researcher a reason for punishment. Each period of your professional career may be dedicated exclusively to one activity - teaching, research or managementand you should only be judged on one if any. (Betty, expert)

Most of those interviewed considered it impossible to combine management with other academic activities, research in particular. This is why weighting for research activities has now become a major concern among teachers in positions of management. Most of the respondents voiced concern at the low value attached to managerial promotion. Academics consider that when appraisals are carried out, managers are at a disadvantage because they are unable to provide evidence of much research activity. There is increasing demand for a balanced model, which considers research, teaching 
and management activities on equal terms. In addition, such a model should include a fair assessment of different merits. As an alternative, a new assessment model has been proposed with a view to integrating these three functions over a specific time period (Ministry of Education, Government of Spain, 2010). This model is geared to establishing whether teachers fulfil their tasks and to monitoring the completion and success they achieve over a period of time. Under this model equal value is attached to all three activities.

\section{Conclusion}

The management model of Catalan public universities, members of which are nonprofessional and democratically elected on a rotational basis, involves the identification of several phases during the mandate of the manager-academic. This study identified three phases with distinct characteristics. The three phases identified reflect the evolution of the academic-manager and is not intended as a predictive model.

The influence that different environments, personal and institutional realities and personal factors can have on the development of academic functions is well known. All the phases described during the analyses of individual positions at universities are almost identical to those reported by Robbins (1987) on the development of human resources in organisations (integration, socialisation, maintenance, negotiation and memory). This study revealed a growing interest in properly defining the phases of development of academic-managers during their activities in universities, an aspect which corresponds with the evidence of Durand (1997). Durand argued that analysis of academic development based on phases allows for an important definition of common profiles among academics. 
The paper identified three well-differentiated phases of development of management functions: learning and contextualisation, development of functions and the institutional projection and transmission of management tasks.

The first period of work, which can be termed the contextualisation phase, implies taking control of the new managerial role and is characterised by a high level of motivation. The leadership style during this phase finds a parallel in the way Mercer (2009) referred to the academic performance of junior managers. Their decisions are often a result of ongoing consultation with individuals or influential groups.

All these characteristics, together with the structures of informal power in departments and university faculties, confer an important role on micro-politics. The development phase requires both maximum effort and exclusive dedication to managerial functions. It is considered the longest of the three phases identified. It is oriented towards the achievement of previously defined objectives and the proper functioning of competences. All programmes are geared to maximising productivity. Evidence derived from preliminary achievements is of crucial importance. From the leadership point of view, this phase affords possibilities to develop new ideas and policies as well as highlighting the need for control mechanism improvements. During the final phase managers reach the maximum level in the development of their functions. Leadership levels are also high, thereby reducing the influence of micro-politics and the need to harness these to maximise general benefit. In the proposed taxonomy of phases, the final one is the most effective as far as the time required for implementation is concerned. The managerial level and the institution as a whole increase their feedback processes, aimed at showing results and objectives achieved. A superior level of institutional awareness also increases its importance. There are also significant benefits at a superior level of institutional awareness. The research found that by undertaking 
managerial positions academics felt a greater sense of institutional belonging. This is very relevant to the preparation of new candidates for managerial positions and the proper planning of future work. According to Strike and Taylor (2009), many people change their perception of their professional career shortly after this phase. Their professional situation tends to be exclusively reoriented towards teaching and research activities.

The research evidenced how each of the three phases identified is characterised by the development of a particular consciousness relating to management functions. During the first phase, the most important aspects are those relating to personal and individual characteristics. The second phase is geared to the development and optimisation of managerial functions. During the final phase, in which managers prepare to step down from the position, the most valuable measure is the achievement of objectives.

These findings may serve as orientation for policy and decision-makers in the Catalan higher education system in two respects. First, they may help determine the cost of a rotational system, in which all unipersonal entities would be renewed every three years. This means that academics would have to take over functions related to the institutional administration of faculties and departments and consequently some features of the three phases looked at in this study would be repeated. Second, the non-professional nature of the position would call for training programmes or advisory services tailored to specific circumstances, the time frame and the individual. It is hoped that in-depth analysis of the features, functions, concerns and concepts associated with every phase will open up new perspectives in the professional development of manager-academics.

\section{References}


Akerlind, G. (2008). "Growing and developing as a university researcher." Higher Education, 55: 241-254

Bricall, J. M' (2000). Informe Universidad dos mil. Madrid, CRUE.

Castro, D. (2006). Los órganos unipersonales de gestión académica en la universidad. Tesis doctoral. Departamento de Pedagogía Aplicada, UAB.

Clark, B. (1983). The Higher Education System: Academic organization in cross national perspective. Los Angeles, University of California Press.

Clark, B. (1995). "Leadership and innovation in Universities. From theory to Practice." Tertiary Education and Management, 1 (1): 7 -11.

Dearing, R. (1997). Higher education in the learning society. London, Department for Learning and Education.

Deem, R. (2006). "Changing research perspectives on the management of Higher Education: Can research permeate the activities of manager-academics?" Higher Education Quarterly, 60(3): 203-228

Deem, R. \& Brehony, K. (2005). "Management as ideology: the case of "new managerialism' in Higher Education." Oxford Review of Education, 31(2): 217-235

Deem, R; Hillyard, S. \& Reed, M. (2007). Knowledge, Higher Education and the New Managerialism: The Changing Management of UK Universities. Oxford, Oxford University Press.

Dolan, S. L. (2003). La gestión de los recursos humanos. Madrid, McGraw Hill.

Durand, J.C. (1997). Dirección y Liderazgo del departamento académico en la universidad. Navarra, EUNSA.

EURYDICE (2008). Higher Education governance in Europe. Policies, structures, funding and academic staff. Brussels, European Commission.

Feixas, M. (2002). El desenvolupament professional del professor universitari com a docent. Tesis doctoral. Departamento de Pedagogía Aplicada, UAB.

Fernández, M. (2006). Desarrollo Profesional Docente. Granada, Grupo Editorial

Flick, U. (2004). Introducción a la investigación cualitativa. Madrid, Morata.

Hancock, T. (2007). "The business of universities and the role of department chair." International journal of educational management. 21 (4): 306-314

Kember, D. (1997). "A reconceptualisation of the research into university academics' conceptions of teaching." Learning and Instruction, 7: 255-257

Kugel, P. (1993). "How professors develop as teachers." Studies in Higher Education. 18 (3): $315-328$

Larsen, I; Maassen, P. \& Stensaker, B. (2009). "Four basic dilemmas in University Governance Reform. Higher Education Management and Policy, 21 (3): 41-57

Mercer, J. (2009). "Junior academic-manager in higher education: an untold story?" International Journal of Educational Management, 23 (4): 248-259

Middlehurst, R. (2004). "Changing internal governance: a discussion of leadership roles and management structures in UK universities." Higher Education Quarterly, 58 (4): 258-279 
Ministerio de Educación. (2010). Estatuto del personal docente e investigador de las universidades españolas. Borrador del decreto. Madrid, Gobierno de España.

Mintzberg, H. (2003). The strategic process. Edinburgh, Prentice Europe.

Mora, J-G. (2000). "El gobierno de las universidades: entre la autonomía y la eficacia". International Seminar on University Governance and Management. Barcelona, EAIR.

Munhall, P. (2001): Qualitative Perspective. Bartlett Publishers

Oja, S. N. (1989). "Teachers: ages and stages of adult development." Holly, M. L. \& McLaughlin, C.S. (Eds.). Perspectives on Teacher Professional Development, London, Falmer Press.

Oxford University (2006). "White Paper on University Governance." Oxford University Gazette, 36: 15-27

Ribbins, P. (2007). "Middle leadership in schools in the UK: improving design - a subject leader's history." International Journal of Leadership in Education, 10(1): $13-30$

Samper, L. (1992). "Carrera professional i cicle vital: continuïtat i canvi en la socialització ocupacional dels docents." Revista de Sociologia, 39: 11-21

Seminar Report (2008). Future business models for universities in the UK: issues and challenges. 1-2 May, Universities UK.

Smith, D. (2008). "Academics or executives? Continuity and change in the roles of provice-chancellors.” Higher Education Quarterly. 62(4): 340-357

Sporn, B. (2003). Management in Higher Education: current trends and future perspectives in European Colleges and Universities. Netherlands, Springer Link.

Strauss, A. \& Corbin, J. (1990). Grounded Theory Procedures and Techniques. Newbury Park, EUA, Sage

Strike, T. \& Taylor, J. (2009). "The career perceptions of academic staff and human resource discourses in English Higher Education." Higher Education Quarterly, 63(2): 177-195

Robertson, D.L. (1999). "Professors' perspectives on their teaching: a new construct and development model." Innovative Higher Education, 23(4): 271-294

Robbins, S. (1987). Comportamiento organizacional. Conceptos, controversias y aplicaciones. Madrid, Prentice Hall.

Tesch, R. (1990). Qualitative Research. NY, Falmer.

Turnbull, S. \& Edwards, G. (2005). "Leadership development for organizational change in a New UK University. Paper presented at the Academy of Human Resource Development International Conference (AHRD) (Estes Park, CO, Feb 24-27, 2005) p. $109-116$

Tomàs, M. (2006). Reconstruir la universidad a través del cambio de cultura. Bellaterra, Servei de publicacions de la UAB

Tomàs, M; Borrell, N; Castro, D; Feixas, M; Bernabeu, D. y Fuentes, M. (2009). La cultura innovadora de las universidades. Barcelona, Octaedro. 
Trackman, L. (2008). "Modelling University Governance." Higher Education Quarterly, 62(1/2): 63-83

Watson, D \& Huxley, L. (2009). "Effective governance in higher education: perspectives and practice". In practice. Leadership Foundation for Higher Education. (Available: www.lfhe.ac.uk (consulted: 14/10/2010) cv

Whitchurch, C. (2007). "The changing roles and identities of professional managers in UK Higher Education." Perspectives: Policy and Practice in Higher Education, 11(2): 53-60.

Zabalza, M. A. (2002). La enseñanza universitaria. El escenario y sus protagonistas. Madrid, Nancea.

\title{
Acknowledgements
}

We should like to thank Professor Rosemary Deem of Royal Holloway, University of London, for her help in commenting on various drafts of this paper.

\section{Biographical notes}

Dr. Diego Castro

Professor of Universitat Autònoma de Barcelona

Edifici G-6

08173- Bellaterra (Spain)

diego.castro@uab.cat

tel. +34935812235

fax. +34935813052

$\mathrm{PhD}$ in Education. Junior Lecturer in Educational Administration at UAB. A member of the research group on Culture Change in Catalan Universities he has conducted research into the role of academic-managers in HE.

\author{
Dr. Marina Tomàs \\ Professor of Universitat Autònoma de Barcelona \\ Edifici G-6 \\ 08173- Bellaterra (Spain) \\ marina.tomas@uab.cat \\ tel. +34935813197 \\ fax. +34935813052
}


$\mathrm{PhD}$ in Education. Senior Lecturer in Educational Administration and Leadership at UAB since 1992. As director of the research group on Culture Change in Catalan Universities she has a particular interest in organisational culture in higher education.

\section{Total number of words: 6306}

